\title{
Study on Macro Kinetics of the Desulfurization Processes of Heteropoly Compounds in Ionic Liquids and Aqueous Solutions
}

\author{
Xinpeng Liu ${ }^{1,2}$, Rui Wang ${ }^{*}$ \\ ${ }^{1}$ Shenzhen Research Institute of Shandong University, Shenzhen, Guangdong 518057, China \\ ${ }^{2}$ School of Environmental Science and Engineering, Shandong University, Qingdao, Shandong 266237, China
}

\begin{abstract}
Ionic liquids and heteropoly compounds have been found to be effective systems for $\mathrm{H}_{2} \mathrm{~S}$ removal due to their unique properties. This study, which investigated the absorption kinetics of these new systems, continues our earlier research. Specifically, the macro kinetic characteristics of the $\mathrm{H}_{2} \mathrm{~S}$ absorption for three systems, viz., a $\left[\mathrm{Bmim}_{3} \mathrm{PMo}_{12} \mathrm{O}_{40} / \mathrm{BmimCl}\right.$ solution, an aqueous solution of peroxo phosphomolybdic acid and an aqueous solution of $\mathrm{CuH}_{2} \mathrm{PMo}_{11} \mathrm{VO}_{40}$, were determined using a gas-liquid reaction cell. The gas and liquid phase mass transfer coefficients were measured, and the activation energy was calculated. The $\mathrm{H}_{2} \mathrm{~S}$ absorption for the $[\mathrm{Bmim}]_{3} \mathrm{PMo}_{12} \mathrm{O}_{40} / \mathrm{BmimCl}$ solution can be expressed as a macro kinetic equation: $\mathrm{N}_{\mathrm{H} 2 \mathrm{~S}}=6.6 \times 10^{-2} \cdot[\exp (-1064 / \mathrm{T})] \cdot \mathrm{C}_{\mathrm{H} 2 \mathrm{~S}}{ }^{1.120} \cdot \mathrm{C}_{[\mathrm{Bmim}] 3 \mathrm{PMo} 12 \mathrm{O} 40^{0.099}}$. For the aqueous solutions of peroxo phosphomolybdic acid and $\mathrm{CuH}_{2} \mathrm{PMo}_{11} \mathrm{VO}_{40}$, the absorption can be expressed as $\mathrm{N}_{\mathrm{H} 2 \mathrm{~S}}=2.68 \times 10^{-6} \cdot[\exp (-790 / \mathrm{T})] \cdot \mathrm{C}_{\mathrm{H} 2 \mathrm{~S}}{ }^{0.252} \cdot \mathrm{C}_{\mathrm{PHPMo}}{ }^{0.131}$ and $\mathrm{N}_{\mathrm{H} 2 \mathrm{~S}}=$ $1.02 \times 10^{-6} \cdot[\exp (607 / \mathrm{T})] \cdot \mathrm{C}_{\mathrm{H} 2 \mathrm{~S}}{ }^{0.510} \cdot \mathrm{C}_{\mathrm{CuH} 2 \mathrm{PM} M 11 \mathrm{VO} 40}{ }^{0.431}$, respectively.
\end{abstract}

Keywords: $\mathrm{H}_{2} \mathrm{~S}$; Absorption; Macro kinetics; Heteropoly compound; Ionic liquid.

\section{INTRODUCTION}

As a common toxic, corrosive gas existing in natural gas, refined gas, biogas and other industrial gases, hydrogen sulfide $\left(\mathrm{H}_{2} \mathrm{~S}\right)$ has threatened the environmental protection and human health seriously (Kashfi and Olson, 2013; Wiheeb et al., 2013; Gupta et al., 2016). In recent years, a large number of works has been focused on the removal of $\mathrm{H}_{2} \mathrm{~S}$, and various desulfurization methods have been developed (Lu et al., 2006; Ko and Hsueh, 2012; Wiheeb et al., 2013). Among these methods, the wet methods which use solutions as desulfurizers play an important position in the field of $\mathrm{H}_{2} \mathrm{~S}$ removal due to their high sulfur load bearing and high desulfurization efficiency (Wang, 2003; Dubois and Thomas, 2010).

Heteropoly compounds (HPCs) have been applied in many fields such as fuel oils desulfurization (Ding and Wang, 2016; Huang et al., 2019). The massive metal atoms existing in heteropoly anion lead to its unique reversible redox property (Pope and Müller, 1991; Kozhevnikov, 1998). As for the removal of $\mathrm{H}_{2} \mathrm{~S}$, HPC solution has been proved as an excellent desulfurizer (Wang, 2003; Zou et al., 2013; Kim et al., 2014). Furthermore, studies reported that the oxygen atom in heteropoly anion could be replaced by $\mathrm{O}_{2}{ }^{2-}$, and then

\footnotetext{
${ }^{*}$ Corresponding author.

E-mail address: wangrui@sdu.edu.cn
}

the peroxo heteropoly compound (PHPC) came into being (Ishii et al., 1988; Yadav and Mistry, 2001). Compared with HPC, the PHPC possesses higher catalytic activity and oxidation property. The PHPC has been applied commonly as catalyst for oxidative desulfurization of fuel oil (Wang et al., 2010a, b; Zhu et al., 2011). However, there are few works on the application of PHPC on $\mathrm{H}_{2} \mathrm{~S}$ removal.

Ionic liquid (IL) has brought about the widespread attention of researcher in related fields because of its unique properties such as low vapor pressure, good thermal stability and dissolving ability for numerous compounds (Bai et al., 2019). Compared with aqueous solution, the solution using IL as solvent could be operated at higher temperature which is higher than the boiling point of water without significant solvent loss. Hence, a series of researches on the desulfurization performance of IL have been reported (Pomelli et al., 2007; Jalili et al., 2009; Safavi et al., 2013). Among these researches, the introduction of active substance has been recognized as an excellent choice to enhance the $\mathrm{H}_{2} \mathrm{~S}$ removal ability of IL-based desulfurizer (Guo et al., 2011; Guo et al., 2015; Huang et al., 2016).

In our previous work, the $\mathrm{H}_{2} \mathrm{~S}$ removal performance of three HPC-based desulfurization systems, $[\mathrm{Bmim}]_{3} \mathrm{PMo}_{12} \mathrm{O}_{40} / \mathrm{BmimCl}$ solution (Bmim: 1- $n$-butyl-3methylimidazolium), aqueous solution of peroxo phosphomolybdic acid (PHPMo) and aqueous solution of $\mathrm{CuH}_{2} \mathrm{PMo}_{11} \mathrm{VO}_{40}(\mathrm{CuPMoV})$, has been investigated (Ma et al., 2016; Liu and Wang, 2017; Liu et al., 2017; Ma et al., 2017). The results showed that all the three systems can 
remove $\mathrm{H}_{2} \mathrm{~S}$ with high efficiencies. In this work, to further understand the reaction characteristics of the desulfurization process of HPC-based system, the macro kinetic characteristics of $\mathrm{H}_{2} \mathrm{~S}$ absorption in three systems were investigated by a double stirred, concentration gradient-less gas liquid reaction cell. The $[\mathrm{Bmim}]_{3} \mathrm{PMo}_{12} \mathrm{O}_{40} / \mathrm{BmimCl}$ system has high thermostability under $250^{\circ} \mathrm{C}$. The three systems were all stable under the temperature of this experiment. The relevant parameters of absorption process were determined, and the macro kinetic equations of practical importance were obtained.

\section{EXPERIMENTAL}

\section{Materials}

Phosphomolybdic acid $\left(\mathrm{H}_{3} \mathrm{PMo}_{12} \mathrm{O}_{40}\right)$ was purchased from Sinopharm Chemical Reagent Co., Ltd., China; 1- $n$-butyl3-methylimidazolium chloride $(\mathrm{BmimCl})$ was supplied by Shanghai Cheng Jie Chemical Co. Ltd., China; hydrogen peroxide $\left(\mathrm{H}_{2} \mathrm{O}_{2}, 30 \%\right)$ was purchased from Laiyang Kant Chemical Co., Ltd., China; phosphoric acid $\left(\mathrm{H}_{3} \mathrm{PO}_{4}, 85 \%\right)$ was purchased from Laiyang Kant Chemical Co., Ltd., China; molybdenum trioxide $\left(\mathrm{MoO}_{3}\right)$ and copper oxide $(\mathrm{CuO})$ were purchased from Tianjin Kermel Chemical Reagent Co., Ltd., China; vanadium pentoxide $\left(\mathrm{V}_{2} \mathrm{O}_{5}\right)$ was purchased from Tianjin Hongyan Chemical Reagents Factory, China.

\section{The Preparation of Desulfurizers}

The $[\mathrm{Bmim}]_{3} \mathrm{PMo}_{12} \mathrm{O}_{40} / \mathrm{BmimCl}$ solution, aqueous PHPMo solution and aqueous $\mathrm{CuPMoV}$ solution were prepared according to our previous reports (Ma et al., 2016; Liu and Wang, 2017; Liu et al., 2017).

\section{The Reaction Cell}

As shown in Fig. 1, the double stirred, concentration gradientless gas liquid reaction cell with an internal diameter of $3.82 \mathrm{~cm}$ and a height of $10 \mathrm{~cm}$ was used to investigate the macro kinetic characteristics of $\mathrm{H}_{2} \mathrm{~S}$ absorption in three systems. The temperature was controlled by thermostat water bath. The gas and liquid agitation was conducted by agitator and rotator, respectively. The stirring speed was adjusted to keep the interface smooth, so the area of gas-liquid interface could be identified as the area of absorption reaction. The specific stirring speed was identified by infrared digital tachometer. In our previous bubbling experiment, the slight foaming phenomenon will occur. However, in this work, the gas and liquid contact directly through the gas-liquid interface in the reaction cell, and no foaming phenomenon could be observed. In this experiment, the desulfurizer was used with relatively high concentration and large amount. As a result, the concentration of desulfurizer had little change in a certain period. A gas mixture (nitrogen as the carrier gas) containing a certain concentration of $\mathrm{H}_{2} \mathrm{~S}$ was passed to the reaction cell at a flow rate of $100 \mathrm{~mL} \mathrm{~min}^{-1}$. The $\mathrm{H}_{2} \mathrm{~S}$ concentration of the outlet gas was detected by a TH-990s hydrogen sulfide gas analyzer. The residual $\mathrm{H}_{2} \mathrm{~S}$ gas was absorbed by aqueous $\mathrm{NaOH}$ solution.

\section{Experimental Methods}

The absorption processes of $\mathrm{H}_{2} \mathrm{~S}$ in the three systems are

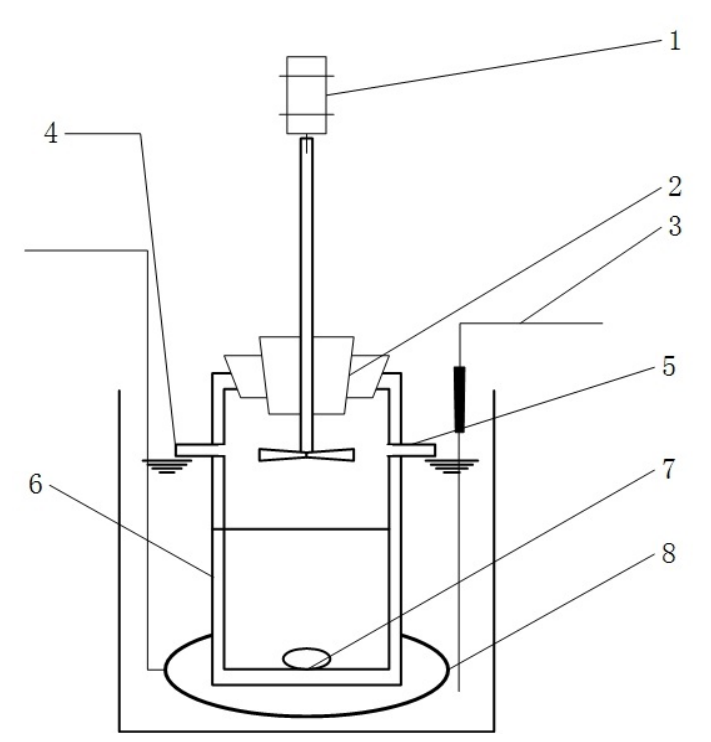

Fig. 1. The double-stirred, concentration gradient-less gas liquid reaction cell: 1 . agitator; 2 . sealing plug; 3 . temperature probe; 4 . gas inlet; 5 . gas outlet; 6 . reaction cell; 7 . rotator; 8 . heating ring.

all mass transfer processes with chemical reaction, including the following three steps:

1) The hydrogen sulfide diffused from gas into gas-liquid interface.

2) The hydrogen sulfide dissolved and diffused into the liquid film at the interface, and reacted with the active component.

3) The reaction products diffused into liquid phase.

In this experiment, the double stirred gas-liquid reaction cell was used to investigate the macro kinetic characteristics of $\mathrm{H}_{2} \mathrm{~S}$ absorption. The mass transfer coefficients of $\mathrm{H}_{2} \mathrm{~S}$ in gas and liquid phase, macro reaction orders and activation energy were determined.

\section{Determination of Gas and Liquid Phase Mass Transfer Coefficients of $\mathrm{H}_{2} \mathrm{~S}$}

The absorption rate of $\mathrm{H}_{2} \mathrm{~S}$ was determined as follows:

$\mathrm{N}_{\mathrm{H} 2 \mathrm{~S}}=\mathrm{V}\left(\mathrm{C}_{1}-\mathrm{C}_{0}\right) / \mathrm{S}$

where $\mathrm{N}_{\mathrm{H} 2 \mathrm{~S}}$ is the absorption rate of $\mathrm{H}_{2} \mathrm{~S}, \mathrm{kmol} \mathrm{m}^{-2} \mathrm{~s}^{-1} ; \mathrm{C}_{1}$ and $\mathrm{C}_{0}$ are the inlet and outlet concentrations of $\mathrm{H}_{2} \mathrm{~S}$ in the reaction cell, respectively, $\mathrm{kmol} \mathrm{m}^{-3}$; $\mathrm{V}$ is the gas flow rate, $\mathrm{m}^{3} \mathrm{~s}^{-1} ; \mathrm{S}$ is the area of gas-liquid interface, $\mathrm{m}^{2}$.

The physical absorption rate of $\mathrm{CO}_{2}$ in deionized water was determined using Eq. (1) under the same conditions. This process was limited by liquid phase mass transfer. The absorption rate can be expressed as:

$$
\begin{aligned}
& \mathrm{N}_{\mathrm{CO} 2}=\mathrm{k}_{\mathrm{LCO} 2}\left(\mathrm{C}^{*}-\mathrm{C}_{\mathrm{L}}\right) \\
& \mathrm{C}^{*}=\mathrm{H} \cdot \mathrm{p}_{\mathrm{CO} 2}
\end{aligned}
$$

where $\mathrm{N}_{\mathrm{CO} 2}$ is the absorption rate of $\mathrm{CO}_{2}, \mathrm{kmol} \mathrm{m}^{-2} \mathrm{~s}^{-1} ; \mathrm{k}_{\mathrm{LCO} 2}$ is the liquid phase mass transfer coefficient of $\mathrm{CO}_{2}, \mathrm{~m} \mathrm{~s}^{-1}$; 
$\mathrm{p}_{\mathrm{CO} 2}$ is the gaseous phase partial pressure of $\mathrm{CO}_{2}, \mathrm{~Pa}$; $\mathrm{H}$ is the solubility coefficient of $\mathrm{CO}_{2}, \mathrm{kmol} \mathrm{m}^{-3} \mathrm{~Pa}^{-1} ; \mathrm{C}_{\mathrm{L}}$ is the concentration of $\mathrm{CO}_{2}$ in the main body of liquid phase. The $\mathrm{k}_{\mathrm{LCO} 2}$ could be determined by Eq. (2), and then the liquid phase mass transfer coefficient of $\mathrm{H}_{2} \mathrm{~S}$ was determined as follows (Weisweiler and Blumhofer, 1984):

$\mathrm{k}_{\mathrm{LH} 2 \mathrm{~S}}=\mathrm{k}_{\mathrm{LCO} 2}\left(\mathrm{D}_{\mathrm{H} 2 \mathrm{~S}} / \mathrm{D}_{\mathrm{CO} 2}\right)^{2 / 3}$

where $\mathrm{k}_{\mathrm{LH} 2 \mathrm{~S}}$ is the liquid phase mass transfer coefficient of $\mathrm{H}_{2} \mathrm{~S}, \mathrm{~m} \mathrm{~s}^{-1}$; $\mathrm{D}_{\mathrm{H} 2 \mathrm{~S}}$ and $\mathrm{D}_{\mathrm{CO} 2}$ are the liquid diffusion coefficient of $\mathrm{H}_{2} \mathrm{~S}$ and $\mathrm{CO}_{2}$, respectively, $\mathrm{m}^{2} \mathrm{~s}^{-1}$.

The absorption rate of $\mathrm{H}_{2} \mathrm{~S}$ in $\mathrm{NaOH}$ solution $\left(1 \mathrm{~mol} \mathrm{~L}^{-1}\right)$ under the same condition was measured using the same method. This process was limited by gas phase mass transfer. The absorption rate can be expressed as:

$\mathrm{N}_{\mathrm{H} 2 \mathrm{~S}}=\mathrm{k}_{\mathrm{GH} 2 \mathrm{~S}} \cdot \mathrm{p}_{\mathrm{H} 2 \mathrm{~S}}$

where $\mathrm{k}_{\mathrm{GH} 2 \mathrm{~S}}$ is the gas phase mass transfer coefficient, kmol $\mathrm{m}^{-2} \mathrm{~s}^{-1} \mathrm{~Pa}^{-1} ; \mathrm{p}_{\mathrm{H} 2 \mathrm{~S}}$ is the gaseous phase partial pressure of $\mathrm{H}_{2} \mathrm{~S}, \mathrm{~Pa}$. So, $\mathrm{k}_{\mathrm{GH} 2 \mathrm{~S}}$ could be determined by measured $\mathrm{N}_{\mathrm{H} 2 \mathrm{~S}}$ and $\mathrm{p}_{\mathrm{H} 2 \mathrm{~S}}$.

\section{Determination of Macro Kinetic Equation of $\mathrm{H}_{2} \mathrm{~S}$ Absorption}

The absorption rate of $\mathrm{H}_{2} \mathrm{~S}$ was correlated with the factors in the reaction by nonlinear fitting method, and then the kinetic reaction orders of the factors were determined. The activation energy of the overall reaction as well as the absorption rate equations were determined by the measured reaction rates at different temperatures as follows:

$\mathrm{N}_{\mathrm{H} 2 \mathrm{~S}}=\mathrm{A} \cdot[\exp (-\mathrm{E} / \mathrm{RT})] \cdot \mathrm{C}_{\mathrm{H} 2 \mathrm{~S}}{ }^{\mathrm{a}} \cdot \mathrm{C}_{\mathrm{absorbent}}{ }^{\mathrm{b}}$

where $\mathrm{A}$ is the pre-exponential factor; $\mathrm{E}$ is the activation energy, $\mathrm{KJ} \mathrm{mol}^{-1}$; $\mathrm{R}$ is the molar gas constant, $8.314 \mathrm{~J} \mathrm{~mol}^{-1}$
$\mathrm{K}^{-1}$; $\mathrm{T}$ is the thermodynamic temperature, $\mathrm{K}$; $\mathrm{a}$ and $\mathrm{b}$ are the reaction orders of the concentrations of $\mathrm{H}_{2} \mathrm{~S}$ and absorbent, respectively.

\section{RESULTS AND DISCUSSION}

\section{The Gas and Liquid Phase Mass Transfer Coefficients of $\mathrm{H}_{2} \mathrm{~S}$}

The experimental results showed that the liquid phase mass transfer coefficient of $\mathrm{CO}_{2}$ at $25^{\circ} \mathrm{C}$ is:

$\mathrm{k}_{\mathrm{LCO} 2}=3.41 \times 10^{-5} \mathrm{~m} \mathrm{~s}^{-1}$

Hence, according to Eq. (4), the liquid phase mass transfer coefficient of $\mathrm{H}_{2} \mathrm{~S}$ at $25^{\circ} \mathrm{C}$ is:

$\mathrm{k}_{\mathrm{LH} 2 \mathrm{~S}}=3.26 \times 10^{-5} \mathrm{~m} \mathrm{~s}^{-1}$

The measured gas phase mass transfer coefficient of $\mathrm{H}_{2} \mathrm{~S}$ at $25^{\circ} \mathrm{C}$ is:

$\mathrm{k}_{\mathrm{GH} 2 \mathrm{~S}}=1.46 \times 10^{-10} \mathrm{kmol} \mathrm{m}^{-2} \mathrm{~s}^{-1} \mathrm{~Pa}^{-1}$

\section{The Macro Kinetic Characteristics of $\mathrm{H}_{2} \mathrm{~S}$ Absorption in $[\mathrm{Bmim}]_{3} \mathrm{PMo}{ }_{12} \mathrm{O}_{40} / \mathrm{BmimCl}$ Solution}

The effect of the concentration of $[\mathrm{Bmim}]_{3} \mathrm{PMo}_{12} \mathrm{O}_{40}$ on the absorption rate was shown in Fig. 2, where $\mathrm{T}$ is the reaction temperature, $r_{G}$ and $r_{L}$ are the stirring rates in gas phase and liquid phase, respectively. It could be seen that the absorption rate increased with the increase of the concentration of $[\mathrm{Bmim}]_{3} \mathrm{PMo}_{12} \mathrm{O}_{40}$. In our previous work (Liu et al., 2017; Ma et al., 2017), the removal of $\mathrm{H}_{2} \mathrm{~S}$ using $[\mathrm{Bmim}]_{3} \mathrm{PMo}_{12} \mathrm{O}_{40} / \mathrm{BmimCl}$ solution has been proved to be achieved by the $[\mathrm{Bmim}]_{3} \mathrm{PMo}_{12} \mathrm{O}_{40}$, and the $\mathrm{BmimCl}$ only played a role of solvent and reaction medium. The increase of the concentration of $[\mathrm{Bmim}]_{3} \mathrm{PMo}_{12} \mathrm{O}_{40}$ is benefit to the decrease of liquid phase mass transfer resistance, thus

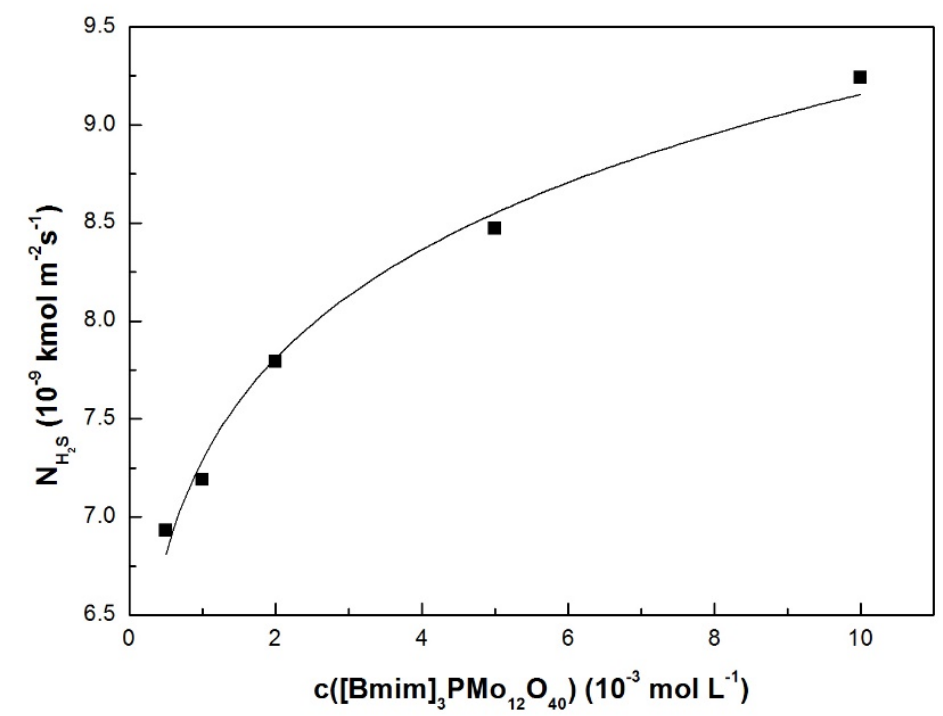

Fig. 2. The effect of $[\mathrm{Bmim}]_{3} \mathrm{PMo}_{12} \mathrm{O}_{40}$ concentration on the absorption rate: $\mathrm{T}=80^{\circ} \mathrm{C}, \mathrm{C}_{\mathrm{H} 2 \mathrm{~S}}=576 \mathrm{mg} \mathrm{m}^{-3}, \mathrm{r}_{\mathrm{G}}=750 \mathrm{r} \mathrm{min}^{-1}$, $\mathrm{r}_{\mathrm{L}}=220 \mathrm{r} \mathrm{min}^{-1}$. 
promoting the absorption of $\mathrm{H}_{2} \mathrm{~S}$. According to nonlinear fitting method, the relation between the concentration of $[\mathrm{Bmim}]_{3} \mathrm{PMo}_{12} \mathrm{O}_{40}$ and absorption rate is:

$$
\mathrm{N}_{\mathrm{H} 2 \mathrm{~S}}=7.29 \times 10^{-9} \mathrm{C}_{[\mathrm{Bmim}] 3 \mathrm{PMo} 12 \mathrm{O} 40^{0.099}}, \mathrm{R}^{2}=0.986
$$

Therefore, the $\mathrm{H}_{2} \mathrm{~S}$ absorption rate in $[\mathrm{Bmim}]_{3} \mathrm{PMo}_{12} \mathrm{O}_{40} / \mathrm{BmimCl}$ solution is proportional to the 0.099 power of the concentration of $[\mathrm{Bmim}]_{3} \mathrm{PMo}_{12} \mathrm{O}_{40}$. This means that the kinetic reaction order of $[\mathrm{Bmim}]_{3} \mathrm{PMo}_{12} \mathrm{O}_{40}$ in the process of $\mathrm{H}_{2} \mathrm{~S}$ absorption is 0.099 .

The effect of the inlet concentration of $\mathrm{H}_{2} \mathrm{~S}$ on the absorption rate is shown in Fig. 3. The $\mathrm{H}_{2} \mathrm{~S}$ absorption rate increased with the increase of the concentration of $\mathrm{H}_{2} \mathrm{~S}$, and the correlation is close to linear relation. The increase of the concentration of $\mathrm{H}_{2} \mathrm{~S}$ could decrease the gas phase mass transfer resistance significantly. According to nonlinear fitting method, the relation between the inlet concentration of $\mathrm{H}_{2} \mathrm{~S}$ and absorption rate is:

$$
\mathrm{N}_{\mathrm{H} 2 \mathrm{~S}}=7.07 \times 10^{-12} \mathrm{C}_{\mathrm{H} 2 \mathrm{~S}}{ }^{1.120}, \mathrm{R}^{2}=0.992
$$

The $\mathrm{H}_{2} \mathrm{~S}$ absorption rate in $[\mathrm{Bmim}]_{3} \mathrm{PMo}_{12} \mathrm{O}_{40} / \mathrm{BmimCl}$ solution is proportional to the 1.120 power of the inlet concentration of $\mathrm{H}_{2} \mathrm{~S}$. This means that the kinetic reaction order of $\mathrm{H}_{2} \mathrm{~S}$ is 1.120 . Compared with the order of concentration of $[\mathrm{Bmim}]_{3} \mathrm{PMo}_{12} \mathrm{O}_{40}$, it could be seen that the major limiting factor of $\mathrm{H}_{2} \mathrm{~S}$ absorption rate in $[\mathrm{Bmim}]_{3} \mathrm{PMo}_{12} \mathrm{O}_{40} / \mathrm{BmimCl}$ solution is gas phase mass transfer resistance.

The effect of absorption temperature on the $\mathrm{H}_{2} \mathrm{~S}$ absorption rate is shown in Fig. 4. The increase of temperature was conductive to the absorption of $\mathrm{H}_{2} \mathrm{~S}$ in $[\mathrm{Bmim}]_{3} \mathrm{PMo}_{12} \mathrm{O}_{40} / \mathrm{BmimCl}$ solution. A higher temperature could decrease the viscosity of ionic liquid, and increase the molecular activity of reactants. As a result, the absorption of $\mathrm{H}_{2} \mathrm{~S}$ was promoted at higher temperature. Hence, according to the results above as well as Eqs. (6), (7) and (8), the activation energy of the overall reaction was calculated as $8.84 \mathrm{KJ} \mathrm{mol}^{-1}$, and the macro kinetic equation of $\mathrm{H}_{2} \mathrm{~S}$ absorption in $[\mathrm{Bmim}]_{3} \mathrm{PMo}_{12} \mathrm{O}_{40} / \mathrm{BmimCl}$ solution is:

$$
\begin{aligned}
\mathrm{N}_{\mathrm{H} 2 \mathrm{~S}}= & 6.6 \times 10^{-2} \cdot[\exp (-1064 / \mathrm{T})] \cdot \mathrm{C}_{\mathrm{H} 2 \mathrm{~S}}{ }^{1.120 .} \\
& \mathrm{C}_{[\text {Bmim }] 3 \mathrm{PMo} 12 \mathrm{O} 40} 0.099
\end{aligned}
$$

The relatively low activation energy demonstrated that the absorption reaction of $\mathrm{H}_{2} \mathrm{~S}$ in $[\mathrm{Bmim}]_{3} \mathrm{PMo}_{12} \mathrm{O}_{40} / \mathrm{BmimCl}$ solution was a diffusion controlled process.

\section{The Macro Kinetic Characteristics of $\mathrm{H}_{2} \mathrm{~S}$ Absorption in Aqueous PHPMo Solution}

The effect of the concentration of PHPMo on the absorption rate is shown in Fig. 5. A higher concentration of PHPMo is in favor of the liquid phase mass transfer process of $\mathrm{H}_{2} \mathrm{~S}$ molecule, which is in agreement with the result of our previous work. Hence, a higher concentration of PHPMo should be chosen in the practical application of $\mathrm{H}_{2} \mathrm{~S}$ removal. The relation between the concentration of PHPMo and absorption rate was determined using nonlinear fitting method as follows:

$\mathrm{N}_{\mathrm{H} 2 \mathrm{~S}}=5.033 \times 10^{-9} \mathrm{C}_{\mathrm{PHPMo}}{ }^{0.131}, \mathrm{R}^{2}=0.962$

Therefore, the $\mathrm{H}_{2} \mathrm{~S}$ absorption rate in aqueous PHPMo solution is proportional to the 0.131 power of the concentration of PHPMo. This means that the kinetic reaction order of PHPMo in the process of $\mathrm{H}_{2} \mathrm{~S}$ absorption is 0.131 .

As shown in Fig. 6, the increase of the inlet concentration of $\mathrm{H}_{2} \mathrm{~S}$ showed a positive influence on the $\mathrm{H}_{2} \mathrm{~S}$ absorption rate due to the decreased gas phase mass transfer resistance. In our previous work, the results showed that the increase of $\mathrm{H}_{2} \mathrm{~S}$ concentration had little effect on the $\mathrm{H}_{2} \mathrm{~S}$ removal efficiency within a certain range, and the $\mathrm{H}_{2} \mathrm{~S}$ removal efficiency would decrease with further increase of $\mathrm{H}_{2} \mathrm{~S}$ concentration. Therefore, an appropriate inlet concentration

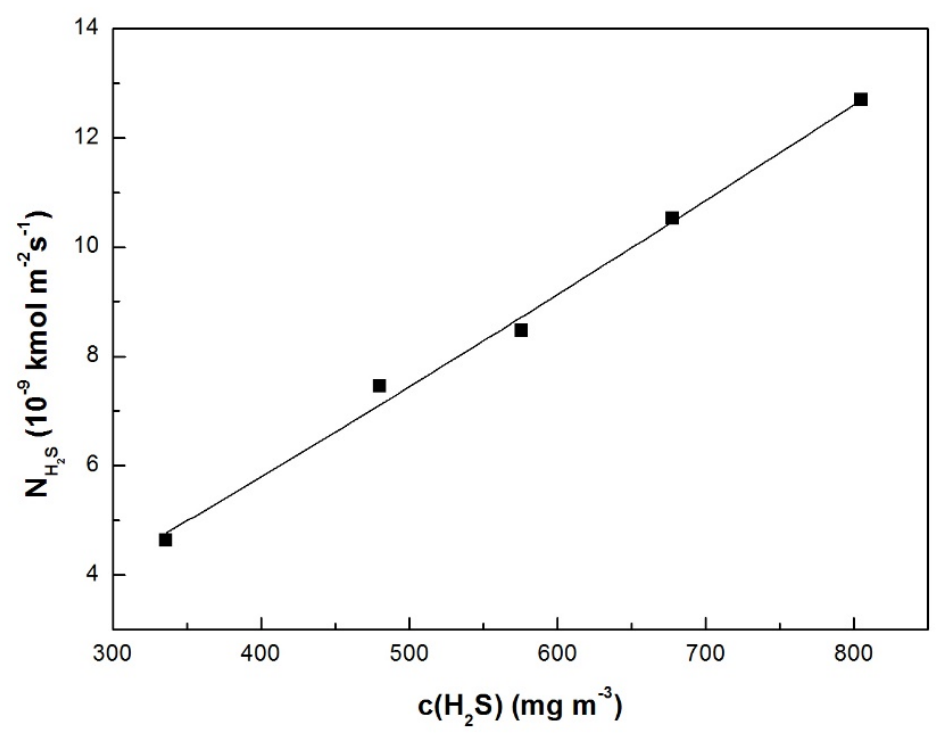

Fig. 3. The effect of the inlet concentration of $\mathrm{H}_{2} \mathrm{~S}$ on the absorption rate: $\mathrm{T}=80^{\circ} \mathrm{C}, \mathrm{C}_{[\mathrm{Bmim}] 3 \mathrm{PMo12}} \mathrm{O}_{40}=0.005 \mathrm{~mol} \mathrm{~L}^{-1}, \mathrm{r}_{\mathrm{G}}=$ $750 \mathrm{r} \mathrm{min}^{-1}, \mathrm{r}_{\mathrm{L}}=220 \mathrm{r} \mathrm{min}^{-1}$. 


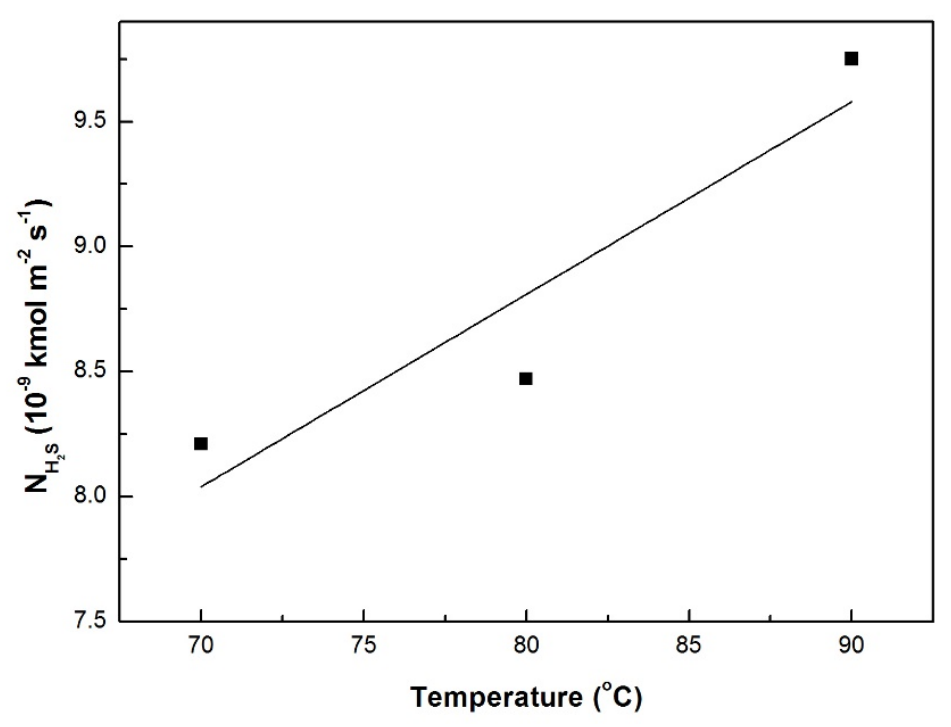

Fig. 4. The effect of temperature on the absorption rate: $\mathrm{C}_{\mathrm{H} 2 \mathrm{~S}}=576 \mathrm{mg} \mathrm{m}^{-3}, \mathrm{C}_{[\mathrm{Bmim}] 3 \mathrm{PMo1} 2} \mathrm{O}_{40}=0.005 \mathrm{~mol} \mathrm{~L}^{-1}, \mathrm{r}_{\mathrm{G}}=750 \mathrm{r} \mathrm{min}^{-1}$, $\mathrm{r}_{\mathrm{L}}=220 \mathrm{r} \mathrm{min}^{-1}$.

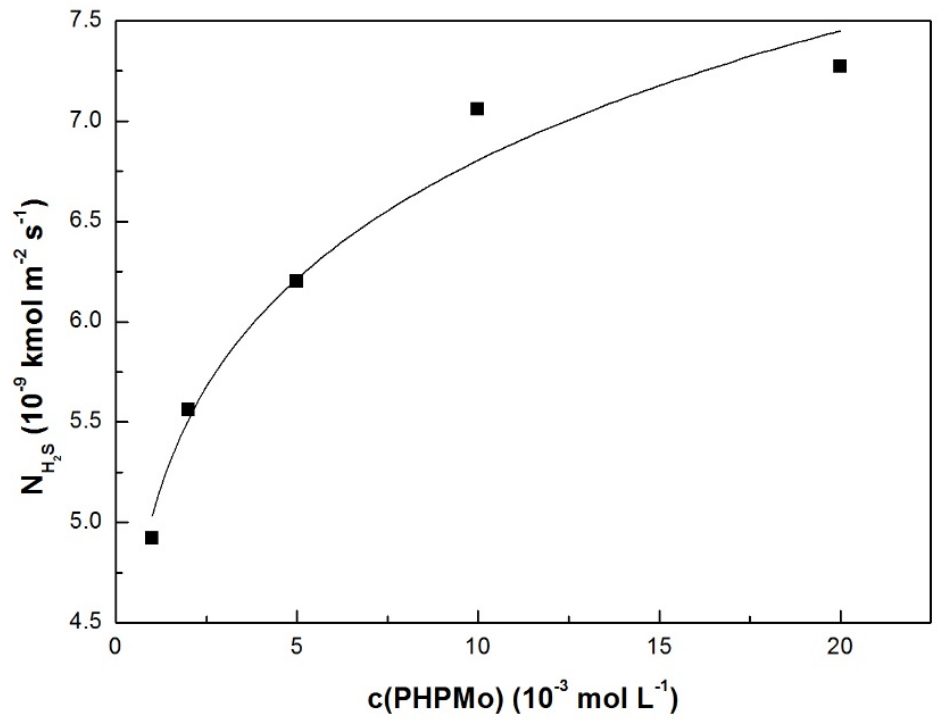

Fig. 5. The effect of the concentration of PHPMo on the absorption rate: $\mathrm{T}=25^{\circ} \mathrm{C}, \mathrm{C}_{\mathrm{H} 2 \mathrm{~S}}=750 \mathrm{mg} \mathrm{m}^{-3}, \mathrm{r}_{\mathrm{G}}=750 \mathrm{r} \mathrm{min}^{-1}, \mathrm{r}_{\mathrm{L}}$ $=220 \mathrm{rmin}^{-1}$.

of $\mathrm{H}_{2} \mathrm{~S}$ should be determined to achieve the highest utilization rate of desulfurizer without the decrease of $\mathrm{H}_{2} \mathrm{~S}$ removal efficiency. Based on nonlinear fitting method, the relation between the inlet concentration of $\mathrm{H}_{2} \mathrm{~S}$ and absorption rate was determined as follows:

$\mathrm{N}_{\mathrm{H} 2 \mathrm{~S}}=1.33 \times 10^{-9} \mathrm{C}_{\mathrm{H} 2 \mathrm{~S}}{ }^{0.252}, \mathrm{R}^{2}=0.989$

The $\mathrm{H}_{2} \mathrm{~S}$ absorption rate in aqueous PHPMo solution is proportional to the 0.252 power of the inlet concentration of $\mathrm{H}_{2} \mathrm{~S}$.

The effect of temperature on the absorption rate is shown in Fig. 7. It could be seen that proper rise in temperature is beneficial to improve the $\mathrm{H}_{2} \mathrm{~S}$ absorption rate because of increased molecular activity at higher temperature. In addition, considering the volatilization of solvent, a moderate temperature should be chosen for practical application. According to the results above as well as Eqs. (6), (10) and (11), the activation energy of the overall reaction was calculated as $6.57 \mathrm{KJ} \mathrm{mol}^{-1}$, demonstrating that the absorption reaction was a diffusion controlled process. The macro kinetic equation of $\mathrm{H}_{2} \mathrm{~S}$ absorption in aqueous PHPMo solution is:

$$
\mathrm{N}_{\mathrm{H} 2 \mathrm{~S}}=2.68 \times 10^{-6} \cdot[\exp (-790 / \mathrm{T})] \cdot \mathrm{C}_{\mathrm{H} 2 \mathrm{~S}}{ }^{0.252} \cdot \mathrm{C}_{\mathrm{PHPMo}}{ }^{0.131}
$$

The Macro Kinetic Characteristics of $\mathrm{H}_{2} \mathrm{~S}$ Absorption in Aqueous CuPMoV Solution

The effect of the concentration of CuPMoV on the absorption rate is shown in Fig. 8. The $\mathrm{H}_{2} \mathrm{~S}$ absorption rate 


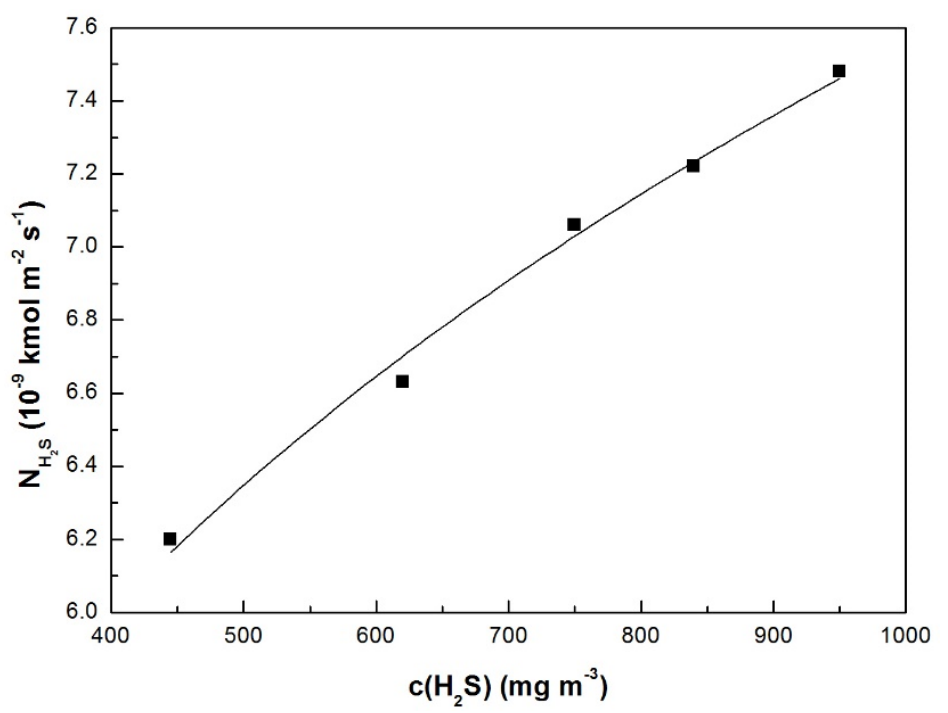

Fig. 6. The effect of the inlet concentration of $\mathrm{H}_{2} \mathrm{~S}$ on the absorption rate: $\mathrm{T}=25^{\circ} \mathrm{C}, \mathrm{C}_{\mathrm{PHPMo}}=0.01 \mathrm{~mol} \mathrm{~L}^{-1}, \mathrm{r}_{\mathrm{G}}=750 \mathrm{rmin}^{-1}$, $\mathrm{r}_{\mathrm{L}}=220 \mathrm{r} \mathrm{min}^{-1}$.

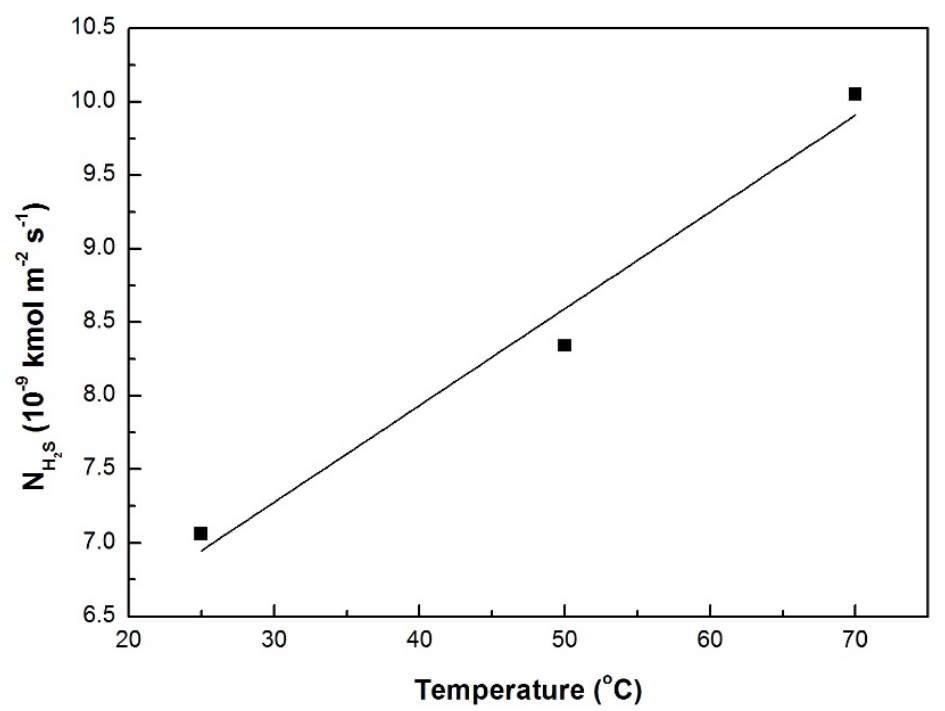

Fig. 7. The effect of temperature on the absorption rate: $\mathrm{C}_{\mathrm{H} 2 \mathrm{~S}}=750 \mathrm{mg} \mathrm{m}^{-3}, \mathrm{C}_{\mathrm{PHPMo}}=0.01 \mathrm{~mol} \mathrm{~L}^{-1}, \mathrm{r}_{\mathrm{G}}=750 \mathrm{r} \mathrm{min}^{-1}, \mathrm{r}_{\mathrm{L}}=$ $220 \mathrm{r} \mathrm{min}^{-1}$.

raise as the concentration of $\mathrm{CuPMoV}$ increased due to the decrease of liquid phase mass transfer resistance. Based on nonlinear fitting method, the relation between the concentration of $\mathrm{CuPMoV}$ and absorption rate was determined as follows:

$\mathrm{N}_{\mathrm{H} 2 \mathrm{~S}}=1.18 \times 10^{-8} \mathrm{C}_{\mathrm{CuH} 2 \mathrm{PMo11VO} 40} 0.431, \mathrm{R}^{2}=0.985$

Hence, the kinetic reaction order of $\mathrm{CuPMoV}$ in the process of $\mathrm{H}_{2} \mathrm{~S}$ absorption is 0.431 .

The effect of the inlet concentration of $\mathrm{H}_{2} \mathrm{~S}$ on the absorption rate is shown in Fig. 9. A higher $\mathrm{H}_{2} \mathrm{~S}$ concentration could promote the gas phase transfer process, and then increase the $\mathrm{H}_{2} \mathrm{~S}$ absorption rate. According to nonlinear fitting method, the relation between the inlet concentration of $\mathrm{H}_{2} \mathrm{~S}$ and absorption rate was determined as follows:
$\mathrm{N}_{\mathrm{H} 2 \mathrm{~S}}=4.63 \times 10^{-10} \mathrm{C}_{\mathrm{H} 2 \mathrm{~S}}{ }^{0.510}, \mathrm{R}^{2}=0.989$

Therefore, the $\mathrm{H}_{2} \mathrm{~S}$ absorption rate in aqueous PHPMo solution is proportional to the 0.510 power of the inlet concentration of $\mathrm{H}_{2} \mathrm{~S}$.

As shown in Fig. 10, differing from the two systems above, the absorption temperature showed a negative effect on the $\mathrm{H}_{2} \mathrm{~S}$ absorption rate. Although the increase of temperature could promote the molecular motion, the increased temperature would hinder the reaction between $\mathrm{CuPMoV}$ and $\mathrm{H}_{2} \mathrm{~S}$, which is exothermic reaction (Wang et al., 2006). Obviously, as for the reaction between $\mathrm{CuPMoV}$ and $\mathrm{H}_{2} \mathrm{~S}$, the negative effect of increased temperature is stronger than its positive effect. According to the results above as well as Eqs. (6), (13) and (14), the activation energy of the overall reaction was calculated as $-5.04 \mathrm{KJ} \mathrm{mol}^{-1}$, and the macro 


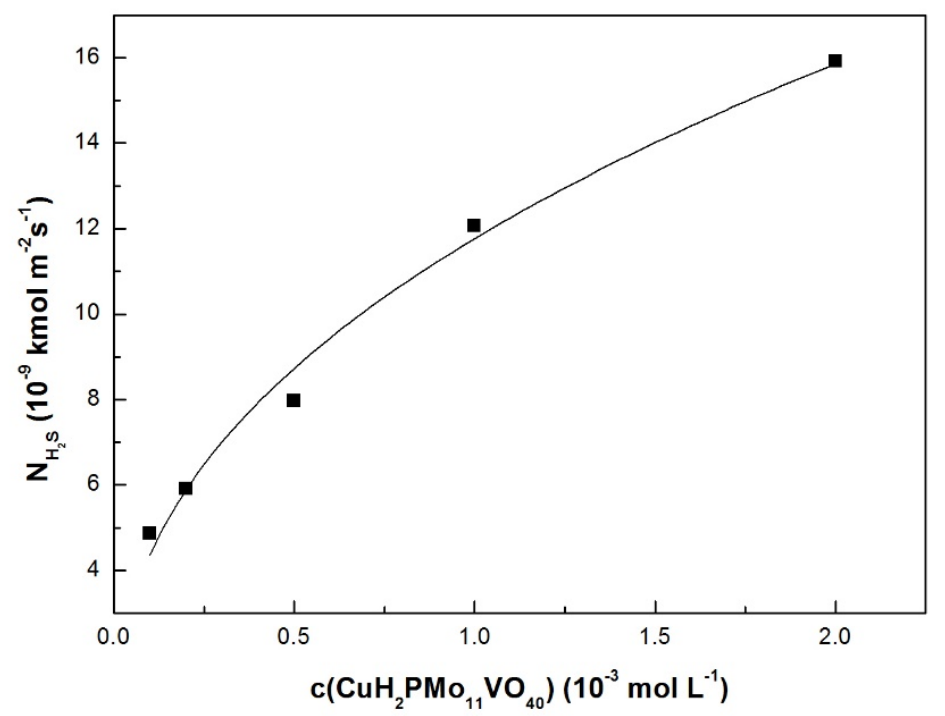

Fig. 8. The effect of the concentration of $\mathrm{CuPMoV}$ on the absorption rate: $\mathrm{T}=25^{\circ} \mathrm{C}, \mathrm{C}_{\mathrm{H} 2 \mathrm{~S}}=600 \mathrm{mg} \mathrm{m}^{-3}, \mathrm{r}_{\mathrm{G}}=750 \mathrm{rmin} \mathrm{m}^{-1}$, $\mathrm{r}_{\mathrm{L}}=220 \mathrm{r} \mathrm{min}^{-1}$.

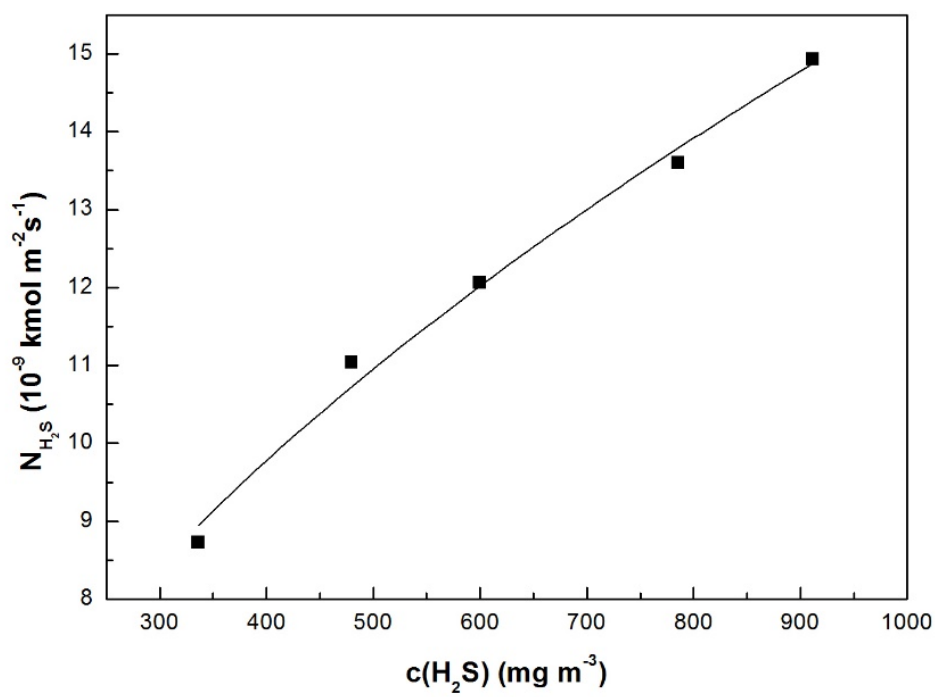

Fig. 9. The effect of the inlet concentration of $\mathrm{H}_{2} \mathrm{~S}$ on the absorption rate: $\mathrm{T}=25^{\circ} \mathrm{C}, \mathrm{C}_{\mathrm{CuPMoV}}=0.001 \mathrm{~mol} \mathrm{~L}^{-1}, \mathrm{r}_{\mathrm{G}}=750 \mathrm{r}$ $\min ^{-1}, r_{L}=220 \mathrm{r} \mathrm{min}^{-1}$.

kinetic equation of $\mathrm{H}_{2} \mathrm{~S}$ absorption in aqueous $\mathrm{CuPMoV}$ solution could be expressed as:

$\mathrm{N}_{\mathrm{H} 2 \mathrm{~S}}=1.02 \times 10^{-6} \cdot[\exp (607 / \mathrm{T})] \cdot \mathrm{C}_{\mathrm{H} 2 \mathrm{~S}}{ }^{0.510} \cdot \mathrm{C}_{\mathrm{CuH} 2 \mathrm{PMo} 11 \mathrm{VO} 40}{ }^{0.431}$

\section{CONCLUSIONS}

Ionic liquids and heteropoly compounds have been found to be effective systems for $\mathrm{H}_{2} \mathrm{~S}$ removal due to their unique properties. In our previous work, three systems for $\mathrm{H}_{2} \mathrm{~S}$ removal, a $[\mathrm{Bmim}]_{3} \mathrm{PMo}_{12} \mathrm{O}_{40} / \mathrm{BmimCl}$ solution, an aqueous PHPMo solution and an aqueous CuPMoV solution, exhibited excellent desulfurization performance. This study continues our earlier research by investigating the macro kinetic characteristics of the three systems' $\mathrm{H}_{2} \mathrm{~S}$ absorption using a double-stirred gas-liquid reaction cell. The gas and liquid phase mass transfer coefficients for $\mathrm{H}_{2} \mathrm{~S}$ in the reaction cell at $25^{\circ} \mathrm{C}$ were $1.46 \times 10^{-10} \mathrm{kmol} \mathrm{m}^{-2} \mathrm{~s}^{-1} \mathrm{~Pa}^{-1}$ and $3.26 \times$ $10^{-5} \mathrm{~m} \mathrm{~s}^{-1}$, respectively. For the $[\mathrm{Bmim}]_{3} \mathrm{PMo}_{12} \mathrm{O}_{40} / \mathrm{BmimCl}$ solution, the orders of the reactions to $[\mathrm{Bmim}]_{3} \mathrm{PMo}_{12} \mathrm{O}_{40}$ and $\mathrm{H}_{2} \mathrm{~S}$ were 0.099 and 1.120 , respectively, and the activation energy of the overall reaction was identified as $8.84 \mathrm{KJ} \mathrm{mol}^{-1}$; these macro kinetics can be expressed with the equation $\mathrm{N}_{\mathrm{H} 2 \mathrm{~S}}$ $=6.6 \times 10^{-2} \cdot[\exp (-1064 / \mathrm{T})] \cdot \mathrm{C}_{\mathrm{H} 2 \mathrm{~S}}{ }^{1.120} \cdot \mathrm{C}_{[\mathrm{Bmim}] 3 \mathrm{PMo} 12 \mathrm{O} 40^{0.099}}$. For the aqueous PHPMo solution, the orders of the reactions to PHPMo and $\mathrm{H}_{2} \mathrm{~S}$ were 0.131 and 0.252 , respectively, and the activation energy of the overall reaction was identified as $6.57 \mathrm{KJ} \mathrm{mol}^{-1}$; these macro kinetics can be expressed with the equation $\mathrm{N}_{\mathrm{H} 2 \mathrm{~S}}=2.68 \times 10^{-6} \cdot[\exp (-790 / \mathrm{T})] \cdot \mathrm{C}_{\mathrm{H} 2 \mathrm{~S}}{ }^{0.252} \cdot \mathrm{C}_{\mathrm{PHPMo}}{ }^{0.131}$. For the aqueous $\mathrm{CuPMoV}$ solution, the orders of the reactions to PHPMo and $\mathrm{H}_{2} \mathrm{~S}$ were 0.131 and 0.252 , and the activation 


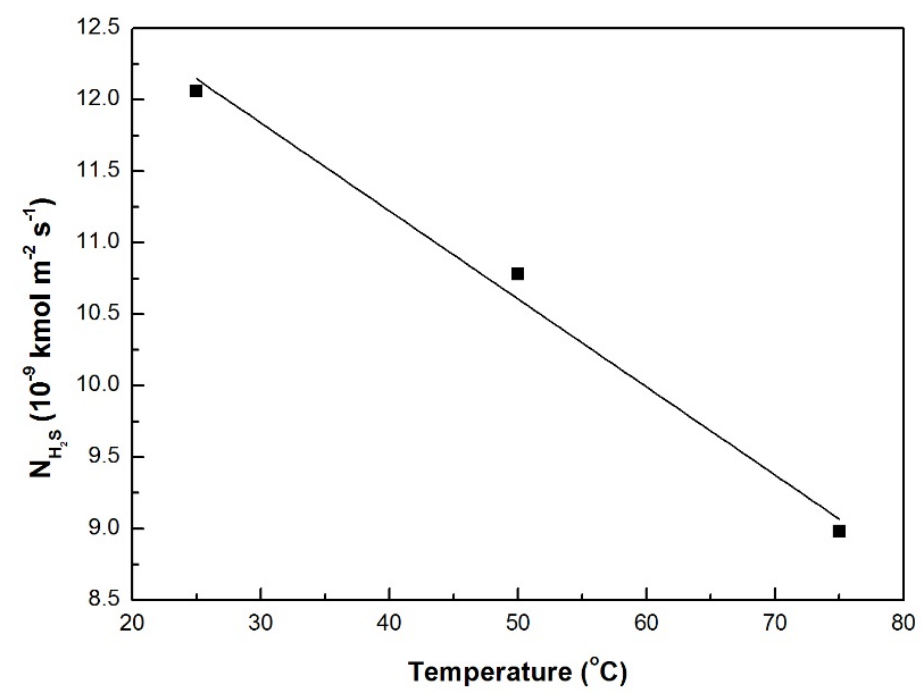

Fig. 10. The effect of temperature on the absorption rate: $\mathrm{C}_{\mathrm{H} 2 \mathrm{~S}}=600 \mathrm{mg} \mathrm{m}^{-3}, \mathrm{C}_{\mathrm{CuPMoV}}=0.001 \mathrm{~mol} \mathrm{~L}^{-1}, \mathrm{r}_{\mathrm{G}}=750 \mathrm{r} \mathrm{min}^{-1}, \mathrm{r}_{\mathrm{L}}$ $=220 \mathrm{r} \mathrm{min}^{-1}$.

energy of the overall reaction was identified as $-5.04 \mathrm{KJ} \mathrm{mol}^{-1}$; these macro kinetics can be expressed with the equation $\mathrm{N}_{\mathrm{H} 2 \mathrm{~S}}=1.02 \times 10^{-6} \cdot[\exp (607 / \mathrm{T})] \cdot \mathrm{C}_{\mathrm{H} 2 \mathrm{~S}}{ }^{0.510} \cdot \mathrm{C}_{\mathrm{CuH} 2 \mathrm{PMo} 11 \mathrm{VO} 40}{ }^{0.431}$. The relatively low activation energy demonstrated that the absorption reactions of $\mathrm{H}_{2} \mathrm{~S}$ in all three systems were driven by diffusion.

\section{ACKNOWLEDGMENTS}

This work was supported by the Scientific Innovation Program of Shenzhen City, China, under Basic Research Program (JCYJ20170818102915033), the National Natural Science Foundation of China (Nos. 21276144 and 21511130021), and the Key Research and Development Program of Shandong Province, China (2017GSF217006).

\section{REFERENCES}

Bai, S., Da, P., Li, C., Wang, Z., Yuan, Z., Fu, F., Kawecki, M., Liu, X., Sakai, N., Wang, J.T.W., Huettner, S., Buecheler, S., Fahlman, M., Gao, F. and Snaith, H.J. (2019). Planar perovskite solar cells with long-term stability using ionic liquid additives. Nature 571: 245250.

Ding, J.W. and Wang, R. (2016). A new green system of HPW@MOFs catalyzed desulfurization using $\mathrm{O}_{2}$ as oxidant. Chin. Chem. Lett. 27: 655-658.

Dubois, L. and Thomas, D. (2010). Comparison of various alkaline solutions for $\mathrm{H}_{2} \mathrm{~S} / \mathrm{CO}_{2}$-selective absorption applied to biogas purification. Chem. Eng. Technol. 33: 1601-1609.

Guo, B., Duan, E., Zhong, Y., Gao, L., Zhang, X. and Zhao, D. (2011). Absorption and oxidation of $\mathrm{H}_{2} \mathrm{~S}$ in caprolactam tetrabutyl ammonium bromide ionic liquid. Energy Fuels 25: 159-161.

Guo, Z., Zhang, T., Liu, T., Du, J., Jia, B., Gao, S. and Yu, J. (2015). Nonaqueous System of iron-based ionic liquid and DMF for the oxidation of hydrogen sulfide and regeneration by electrolysis. Environ. Sci. Technol. 49: 5697-5703.

Gupta, A.K., Ibrahim, S. and Al Shoaibi, A. (2016). Advances in sulfur chemistry for treatment of acid gases. Prog. Energy Combust. Sci. 54: 65-92.

Huang, K., Zhang, X.M., Hu, X.B. and Wu, Y.T. (2016). Hydrophobic protic ionic liquids tethered with tertiary amine group for highly efficient and selective absorption of $\mathrm{H}_{2} \mathrm{~S}$ from $\mathrm{CO}_{2}$. AIChE J. 62: 4480-4490.

Huang, T., He, S., Chang, J., Xu, Y. and Fan, Y. (2019). Preparation of a superior $\mathrm{Co}_{4} \mathrm{Mo}_{12} / \mathrm{Al}_{2} \mathrm{O}_{3}$ hydrodesulfurization catalyst by the hydrothermal deposition of heteropoly compounds on $\mathrm{Al}_{2} \mathrm{O}_{3}$. Catal. Commun. 122: 68-72.

Ishii, Y., Yamawaki, K., Ura, T., Yamada, H., Yoshida, T. and Ogawa, M. (1988). Hydrogen peroxide oxidation catalyzed by heteropoly acids combined with cetylpyridinium chloride. Epoxidation of olefins and allylic alcohols, ketonization of alcohols and diols, and oxidative cleavage of 1,2-diols and olefins. J. Org. Chem. 53: 3581-3593.

Jalili, A.H., Rahmati-Rostami, M., Ghotbi, C., HosseiniJenab, M. and Ahmadi, A.N. (2009). Solubility of $\mathrm{H}_{2} \mathrm{~S}$ in ionic liquids $[\mathrm{bmim}]\left[\mathrm{PF}_{6}\right],[\mathrm{bmim}]\left[\mathrm{BF}_{4}\right]$, and $[\mathrm{bmim}]\left[\mathrm{Tf}_{2} \mathrm{~N}\right]$. J. Chem. Eng. Data 54: 1844-1849.

Kashfi, K. and Olson, K.R. (2013). Biology and therapeutic potential of hydrogen sulfide and hydrogen sulfidereleasing chimeras. Biochem. Pharmacol. 85: 689-703.

Kim, K., Song, D. and Han, J.I. (2014). A liquid redox sulfur recovery process based on heteropoly molybdophosphate (HPMo) with electricity generation. Chem. Eng. J. 241: 60-65.

Ko, T.H. and Hsueh, H.T. (2012). Removal of hydrogen sulfide by iron-rich soil: Application of the deactivation kinetic model for fitting breakthrough curve. Aerosol Air Qual. Res. 12: 1355-1361.

Kozhevnikov, I.V. (1998). Catalysis by heteropoly acids and multicomponent polyoxometalates in liquid-phase reactions. 
Chem. Rev. 98: 171-198.

Liu, X. and Wang, R. (2017). An innovative approach to oxidative removal of hydrogen sulfide using the solution of peroxo heteropolyacid. Aerosol Air Qual. Res. 17: 1341-1346.

Liu, X., Li, J. and Wang, R. (2017). Desulfurization and regeneration performance of heteropoly compound/ionic liquid solutions at high temperature. Chem. Eng. J. 316: 171-178.

Lu, J.G., Zheng, Y.F. and He, D.L. (2006). Selective absorption of $\mathrm{H}_{2} \mathrm{~S}$ from gas mixtures into aqueous solutions of blended amines of methyldiethanolamine and 2-tertiarybutylamino-2-ethoxyethanol in a packed column. Sep. Purif. Technol. 52: 209-217.

Ma, Y.Q., Liu, X.P., Li, J.P., Wang, R. and Yu, M.Q. (2016). Transition metal salts of $\mathrm{H}_{4} \mathrm{PMo}_{11} \mathrm{VO}_{40}$ for efficient $\mathrm{H}_{2} \mathrm{~S}$ removal in the liquid redox process. Chem. Pap. 71: 647652.

Ma, Y., Liu, X. and Wang, R. (2017). Efficient removal of $\mathrm{H}_{2} \mathrm{~S}$ at high temperature using the ionic liquid solutions of $\left[\mathrm{C}_{4} \mathrm{mim}\right]_{3} \mathrm{PMo}_{12} \mathrm{O}_{40}-\mathrm{An}$ organic polyoxometalate. $J$. Hazard. Mater. 331: 109-116.

Pomelli, C.S., Chiappe, C., Vidis, A., Laurenczy, G. and Dyson, P.J. (2007). Influence of the interaction between hydrogen sulfide and ionic liquids on solubility: Experimental and theoretical investigation. J. Phys. Chem. B 111: 13014-13019.

Pope, M.T. and Müller, A. (1991). Polyoxometalate chemistry: An old field with new dimensions in several disciplines. Angew. Chem. Int. Ed. 30: 34-48.

Safavi, M., Ghotbi, C., Taghikhani, V., Jalili, A.H. and Mehdizadeh, A. (2013). Study of the solubility of $\mathrm{CO}_{2}$, $\mathrm{H}_{2} \mathrm{~S}$ and their mixture in the ionic liquid 1-octyl-3methylimidazolium hexafluorophosphate: Experimental and modelling. J. Chem. Thermodyn. 65: 220-232.

Wang, L., Cao, B., Wang, S. and Yuan, Q. (2006). $\mathrm{H}_{2} \mathrm{~S}$ catalytic oxidation on impregnated activated carbon:
Experiment and modelling. Chem. Eng. J. 118: 133-139.

Wang, R. (2003). Investigation on a new liquid redox method for $\mathrm{H}_{2} \mathrm{~S}$ removal and sulfur recovery with heteropoly compound. Sep. Purif. Technol. 31: 111-121.

Wang, R., Yu, F., Zhang, G. and Zhao, H. (2010a). Performance evaluation of the carbon nanotubes supported $\mathrm{Cs}_{2.5} \mathrm{H}_{0.5} \mathrm{PW}_{12} \mathrm{O}_{40}$ as efficient and recoverable catalyst for the oxidative removal of dibenzothiophene. Catal. Today 150: 37-41.

Wang, R., Zhang, G. and Zhao, H. (2010b). Polyoxometalate as effective catalyst for the deep desulfurization of diesel oil. Catal. Today 149: 117-121.

Weisweiler, W. and Blumhofer, R. (1984). Absorption of $\mathrm{NO}_{x}$ in aqueous solutions of $\mathrm{Na}_{2} \mathrm{SO}_{3} / \mathrm{NaHSO}_{3}$ and simultaneous absorption of $\mathrm{NO}_{x}$ and $\mathrm{SO}_{2}$ in $\mathrm{NaOH}$ (by means of a double stirred cell). Ger. Chem. Eng. 4: 241247.

Wiheeb, A.D., Shamsudin, I.K., Ahmad, M.A., Murat, M.N., Kim, J. and Othman, M.R. (2013). Present technologies for hydrogen sulfide removal from gaseous mixtures. Rev. Chem. Eng. 29: 449-470.

Yadav, G. and Mistry, C. (2001). Oxidation of benzyl alcohol under a synergism of phase transfer catalysis and heteropolyacids. J. Mol. Catal. A: Chem. 172: 135-149.

Zhu, W., Zhu, G., Li, H., Chao, Y., Chang, Y., Chen, G. and Han, C. (2011). Oxidative desulfurization of fuel catalyzed by metal-based surfactant-type ionic liquids. J. Mol. Catal. A: Chem. 347: 8-14.

Zou, C., Zhao, P., Ge, J., Qin, Y. and Luo, P. (2013). Oxidation/adsorption desulfurization of natural gas by bridged cyclodextrins dimer encapsulating polyoxometalate. Fuel 104: 635-640.

Received for review, September 16, 2019

Revised, October 25, 2019 Accepted, November 14, 2019 